\title{
Are inflected geotherms real?
}

Lee, C. $-\mathrm{T}^{1}$

1. Department of Earth and Planetary Sciences, Harvard University, Cambridge, MA, 02138

High temperature sheared peridotites (HTSPs) plot on an inflected or kinked geotherm for most methods of calculation as shown in Fig. 1 (see Finnerty and Boyd, 1987). They are distinguished from the low temperature granular peridotites (LTPs) by having higher equilibration pressures and temperatures, sheared deformation textures (Bouiller and Nicolas, 1973), and more fertile compositions (Boyd, 1973). Their uniqueness is further illustrated by a gap in P-T space between the LTPS and the HTSPs, a correlation between the depth of the kink and thermal state of the mantle (Boyd and Gurney, 1986), and calculated temperatures which are higher than mantle adiabatic temperatures for a given depth.

Interpretation of the HTSPs has been controversial. A popular belief has been that the HTSPs are samples from the top of the fertile, convecting asthenosphere (Basu et al., 1986). In this sense, the kink is interpreted to be an ambient feature (Boullier and Nicolas, 1973), although shearheating has been advocated by others (Kesson and Ringwood, 1989). However, it is now established from Re-Os isotope studies that there exists no fundamental difference between the HTSPs and the peridotites which lie above them (Walker et al., 1989; Pearson et al., 1995). Instead, the more fertile character of the HTSPs are likely to be related to reaction with the host magma (Harte, 1983). Such samples do not represent fertile, convecting asthenosphere. Moreover, if the pressures and temperatures calculated for the HTSPs are real, then the presence of a kink in a geotherm requires that the conditions that formed them must be transient. Preserved chemical zoning profiles in many mineral grains further indicate that many of the characteristics of the HTSPs are imparted shortly before entrainment into the host magma (Smith, 1988).

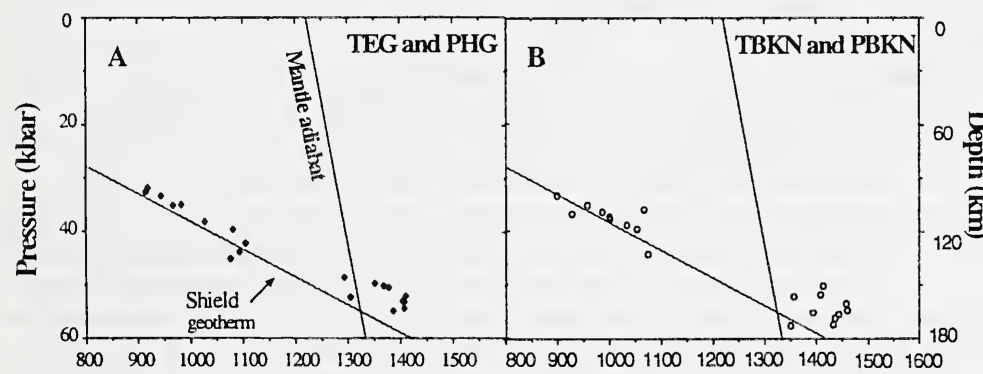

Temperature (Celsius)

Fig. 1 Equilibration pressures and temperatures for gt-bearing xenoliths from one kimberlite in Lesotho, South Africa (Nixon and Boyd, 1973) using A) a gt-cpx thermometer (Ellis and Green, 1979) and a Al-in-opx barometer (Harley and Green, 1982), and B) a two-px thermometer and a Alin-opx barometer (Brey and Kohler, 1990).

\section{Is the kinked geotherm an artifact of disequilibrium thermobarometry?}

Certain features of the HTSPs appear to have originated shortly before eruption. Could the kinked geotherm be an artifact of disequilibrium thermobarometry? I propose as a working hypothesis, that the HTSPs represent samples which have undergone short-lived isobaric heating. Heating by the host magma has been advocated by others as well (Gurney and Harte, 1980).

I examined the Ellis and Green gt-cpx exchange thermometer (TEG) (1979) and the Harley and Green Al-in-opx gt-opx barometer (PHG) (1982), which are among the coupled equations which give inflected geotherms. The TEG thermometer depends primarily on the exchange of $\mathrm{Fe}$ and $\mathrm{Mg}$ between gt and cpx. The PHG barometer depends primarily on the Al solubility in opx coexisting with gt. Self-diffusion coefficients (D) for the divalent cations, $\mathrm{Mn}, \mathrm{Mg}$, and Fe, are 
approximately $10^{-17} \mathrm{~m}^{2} / \mathrm{s}$ at $1200{ }^{\circ} \mathrm{C}$ in gt (Loomis et al., 1985). From empirical observations, Cohen et al. (1988) showed that diffusion coefficients for divalent cations in cpx are comparable. The diffusion coefficient of the trivalent cation, $\mathrm{Al}$, in pyroxenes is believed to be much smaller than that for divalent cations. Sautter et al. (1988) deduced from experiments that $D^{\mathrm{Al}}$ in diopside was $10^{-21} \mathrm{~m}^{2} / \mathrm{s}$ at $1200{ }^{\circ} \mathrm{C}$ while Smith et al. (1991) found a value of $10^{-25}$ at $800{ }^{\circ} \mathrm{C}$ for opx. For $1200{ }^{\circ} \mathrm{C}$, a value of $8 \times 10^{-20} \mathrm{~m}^{2} / \mathrm{s}$ for $\mathrm{D}^{\mathrm{Al}}$ in opx is obtained. Diffusion modeling studies of preserved trace-element zoning in mineral grains from HTSPs indicate that the thermal perturbation lasted on the order of only hundreds to thousands of years (Griffin et al., 1989). The approximate distance to which a chemical perturbation can propagate is given by $x=\sqrt{\mathrm{Dt}}$ where $\mathrm{x}$ is distance and $t$ is time. In 10,000 years a divalent cation can propogate $\sim 1.7 \mathrm{~mm}$ while a trivalent cation such as Al propagates only $0.017 \mathrm{~mm}$. Since the average radii of minerals in the peridotites are $1-3 \mathrm{~mm}$, diffusion of $\mathrm{Mg}$ and $\mathrm{Fe}$ are significant while diffusion of $\mathrm{Al}$ can be ignored. Thus, core compositions can be changed by diffusion for $\mathrm{Mg}$ and $\mathrm{Fe}$, but not for $\mathrm{Al}$. This implies that the $\mathrm{Mg}$ Fe exchange thermometer, TEG, will have responded considerably to our thermal perturbation, and thus isopleths of the equilibrium constant, $K_{C}=X_{\mathrm{Fe}}^{G t} X_{M g}^{C p x} / X_{M g}^{G t} X_{\mathrm{Fe}}^{\mathrm{Cp} x}$, will move to higher temperatures in P-T space. But PHG, which relies on $\mathrm{Al}$ solubility in orthopyroxene, will have barely responded to the new thermal conditions. As a result, calculating Ps and Ts with equations based on cations with different diffusional kinetics can lead to serious error. As shown in Fig. 2a, "apparent" Ps and Ts will result in an array of P-T points that plot along the PHG isopleth, over-estimating pressures and resulting in an artificial geotherm.

\section{Temperature (Celsius)}

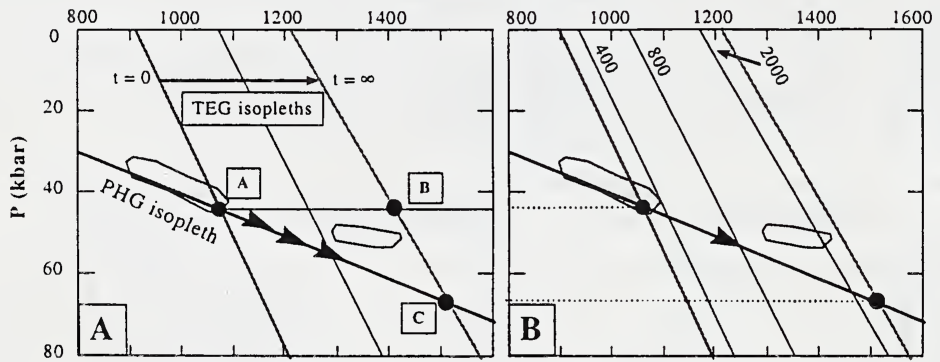

Fig. 2. A. Schematic illustrating the effect of disequilibrium thermobarometry for mantle xenoliths. When a rock at $A$ is subject to an isobaric heating to $1400{ }^{\circ} \mathrm{C}$ for short duration $(<10,000$ years), isopleths of the $\mathrm{Mg}$-Fe exchange thermometer (TEG) respond by moving to higher temperature, but isopleths of the Al-solubility barometer (PHG) do not have sufficient time to respond (assumed here to be frozen). Since $\mathrm{P}$ and $\mathrm{T}$ are determined from the intersection of the two isopleths, apparent Ps and Ts will follow the trajectory from A to C. Although the true conditions are B, pressures will be overestimated, leading to an artificial geotherm. Gray regions represent the data from Figure 1. B. Results of diffusion modeling where TEG isopleths as a function of time (years) are calculated from compositions of coexisting gt and cpx cores. Apparent Ps and Ts are calculated from the intersection of TEG and PHG isopleths. Because Aldiffusion is so slow, PHG isopleths are assumed to be frozen, which gives a maximum value for apparent pressures. Diffusion modeling assumes exchange of $\mathrm{Mg}$ and $\mathrm{Fe}$ between spherical gt and $\mathrm{cpx}$ grains in a closed system. Initial condition is specified by the deepest of the LTPs in Fig. 1, and by applying the boundary condition determined from the equilibrium compositions for an isobaric thermal perturbation to $1400^{\circ} \mathrm{C}$ and from mass balance considerations. Radii of gt and cpx assumed to be $2.5 \mathrm{~mm}$, gt:cpx assumed to be 1:1, and the diffusion coefficient for $\mathrm{Mg}$ and $\mathrm{Fe}$ for both garnet and clinopyroxene assumed to be $10^{-16} \mathrm{~m}^{2} / \mathrm{s}$ at $1400^{\circ} \mathrm{C}$.

In Fig. 2b, I present the results of diffusion modeling (details in figure caption). An inflected P-T array originating from the deepest of the LTPs can be generated by varying the duration of heating. The array can also be produced by heating minerals with variable grain sizes. 
Additionally, the higher scatter observed for the HTSPs can be explained if there are variable mineral cross-sections revealed in thin sections. The gap in the P-T array can be explained by the fact that TEG has more or less responded to the thermal perturbation. The most important feature of our modeling is that isobaric heating of the deepest LTP yields "apparent" Ps and Ts which are close to those calculated for the HTSPs. Note that the assumption of a frozen PHG isopleth gives a maximum value for "apparent" $\mathrm{P}$. If diffusion is allowed to occur, then the apparent Ps will be lower and approach point B in Fig. 2a. The working hypothesis succeeds in explaining many features of the inflected geotherm. Could the HTSPs all be derived from the same depth?

\section{References}

Basu, A. R., Ongley, J. S., and MacGregor, I. D., 1986, Eclogites, pyroxene geotherm, and layered mantle convection: Science, v. 233, p. 1303-1305.

Boullier, A. M. and Nicolas, A., 1975, Classification of textures and fabrics of peridotite xenoliths from South African kimberlites: in Ahrens, L. H., ed., Physics and Chemistry of the Earth, v. 9, p. 467-475.

Boyd, F. R., 1973, A pyroxene geotherm: Geochimica Cosmochimica Acta, v. 37, p. 2533-2546.

Boyd, F. R. and Gurney, J. J., 1986, Diamonds and the African lithosphere: Science, v. 232, p. 472-477.

Brey, G. P. and Kohler, T., 1990, Geothermobarometry in four-phase lherzolites II. New thermobarometers, and practical assessment of existing thermobarometers: Journal of Petrology, v. 31, p. 1353-1378.

Cohen, A. S., O'Nions, R. K., Segenthaler, R., and Griffin, W. L., 1988, Chronology of the pressure-temperature history recorded by a granulite terrain: Contributions to Mineralogy and Petrology, v. 98, p. 303-311.

Ellis, D. J. and Green, D. H., 1979, An experimental study of the effect of Ca upon garnet-clinopyroxene Fe-Mg exchange equilibria: Contributions to Mineralogy and Petrology, v. 71, p. 13-22.

Finnerty, A. A. and Boyd, F. R., 1987, Thermobarometry for garnet peridotites: basis for the determination of thermal and compositional structure of the upper mantle, in Nixon, P. H., ed., Mantle Xenoliths: New York, NY, John Wiley and Sons, p. 381-402.

Griffin, W. L., Smith, D., Boyd, F. R., Cousens, D. R., Ryan, C. G., Sie, S. H., and Suter, G. F., 1989, Trace-element zoning in garnets from sheared mantle xenoliths: Geochimica Cosmochimica Acta, v. 53, p. 561-567.

Gurney, J. J. and Harte, B., 1980, Chemical variations in upper mantle nodules from South African kimberlites: Philosophical Transactions of Royal Society of London A, v. 297, p. 273-293.

Harley, S. L. and Green, D. H., 1982, Garnet-orthopyroxene barometry for granulites and peridotites: Nature, v. 300, p. 697-701.

Harte, B., 1983, Mantle peridotites and processes-the kimberlite sample, in Hawskedworth, C. J. and Norry, M. J., eds., Continental Basalts and Mantle Xenoliths: Nantwich, United Kingdom, Shiva Publications, p. 46-91.

Kesson, S. E. and Ringwood, A. E., 1989, Slab-mantle interactions 1. Sheared and refertilised garnet peridotite xenoliths - samples of Wadati-Benioff zones?: Chemical Geology, v. 78, p. 83-96.

Loomis, T. P., Ganguly, J., and Elphick, S. C., 1985, Experimental determination of cation diffusivities in aluminosilicate garnets II. Multicomponent simulation and tracer diffusion coefficients: Contributions to Mineralogy and Petrology, v. 90, p. 45-51.

Nixon, P. H. and Boyd, F. R., 1973, Petrogenesis of the granular and sheared ultrabasic nodule suite in kimberlite, in Nixon, P. H., ed., Lesotho Kimberlites: South Africa, Lesotho National Development Corporation, p. 48-56.

Pearson, D. G., Carlson, R. W., Shirey, S. B., Boyd, F. R., and Nixon, P. H., 1995, Stabilisation of Archaean lithospheric mantle: A Re-Os isotope study of peridotite xenoliths from the Kaapvaal craton: Earth and Planeatry Science Letters, v. 134, p. 341-357.

Sautter, V., Jaoul, O., and Abel, F., 1988, Aluminum diffusion in diopside using the ${ }^{27} \mathrm{Al}(\mathrm{p}, \gamma)^{28} \mathrm{Si}$ nuclear reaction: preliminary results: Earth and Planetary Science Letters, v. 89, p. 109-114.

Smith, D., 1988, Implications of zoned garnets for the evolution of sheared lherzolites: examples from northern Lesotho and the Colorado Plateau: Journal of Geophysical Research, v. 93, p. 4895-4905.

Smith, D. and Barron, B. R., 1991, Pyroxene-garnet equilibration during cooling in the mantle: American Mineralogist, v. 76, p. 1950-1963.

Walker, R. J., Carlson, R. W., Shirey, S. B., and Boyd, F. R., 1989, Os, Sr, Nd, and Pb isotope systematics of southern African peridotite xenoliths: Implications for the chemical evolution of subcontinental mantle: Geochimica Cosmochimica Acta, v. 53, p. 1583-1595. 